\title{
KINERJA PENYULUH PERTANIAN DAN KEBERHASILAN KELOMPOK PEMASARAN BERSAMA BAHAN OLAHAN KARET RAKYAT (BOKAR) DI KABUPATEN KUANTAN SINGINGI
}

\author{
MELI SASMI ${ }^{1}$, MAHRANI ${ }^{2}$, HARIS SUSANTO ${ }^{3}$ \\ ${ }^{123}$ Dosen Fakultas Pertanian Universitas Islam Kuantan Singingi
}

\begin{abstract}
ABSTRAK
Penelitian ini dilakukan di Kabupaten Kuantan Singingi bertujuan mengetahui kinerja penyuluh pertanian dan keberhasilan kelompok pemasaran bersama bahan olahan karet rakyat (Bokar) di Kabupaten Kuatan Singingi. Penelitian dilakukan dengan metode survey dengan mengumpulkan data primer dan sekunder. Untuk menganalisis data diukur dengan menerapkan "Skala Likert" yang diukur adalah variabel kinerja, pengetahuan, keterampilan, motivasi, jarak tempat tingal, fasilitas dan keberhasilan anggota kelompok dalam pengembangan usaha kelompok pemasaran secara bersama, diukur dengan skala jenjang lima $(1,2,3,4,5)$.

Hasil penelitian menunjukkan bahwa kinerja penyuluh pertanian berdasarkan sifat personalitas dan hasil kerja memiliki kategori baik hal ini disebabkan oleh penyuluh memiliki sifat tekun, disiplin, kerja keras, bertanggung jawab, inovatif, kreatif dan ketauladanan yang baik. Kinerja berdasarkan hasil kerja juga memiliki kategori baik dilihat dari frekuensi penyuluhan, materi penyuluhan, program penyuluhan, kehadiran sasaran yang baik, interaksi penyuluh dengan kelompok tani dan perubahan perilaku sasaran sangat baik, perkembangan kegiatan pemasaran bersama bokar baik serta manajemen usaha pemasaran bersama bokar juga baik. Berdasarkan faktor-faktor mempengaruhi kinerja penyuluh pengetahuan memiliki kategori, keterampilan, motivasi yang baik, sikap penyuluh sangat baik, jarak tempat tinggal dekat namun fasilitas kurang lengkap.

Keberhasilan anggota kelompok dalam mengembangkan usaha kelompok pemasaran bokar secara bersama memiliki kategori baik terlihat dari pertambahan volume penjualan. Persentase kadar karet kering, pengolahan bokar, pendapatan anggota, jumlah usaha yang dimiliki, penerapan teknologi, permodalan, pemasaran. Pendapatan anggota yang baik dan permodalan yang sangat baik hal ini terlihat dari berkembangnya usaha kelompok dengan menumbuhan usaha-usaha produktif pada kelompok pemasaran tersebut.
\end{abstract}

Kata Kunci : Kinerja,penyuluh,keberhasilan.

\section{PENDAHULUAN}

Tanaman karet di Kabupaten Kuantan Singingi merupakan komoditi unggulan yang diusahakan secara turun temurun, namun permasalahan yang dihadapi petani adalah harga bahan olahan karet rakyat (bokar) beberapa tahun terakhir terus mengalami penurunan dan sangat berdampak terhadap melemahnya daya beli masyarakat, hal ini sangat mempengaruhi terhadap perkembangan perekonomian di Kabupaten Kuantan Singingi.

Bahan olahan karet rakyat (Bokar) ditingkat petani umumnya dijual melalui pedagang pengumpul didesa dengan mutu bokar yang beragam, disebabkan kurangnya fasilitas pemasaran, lembaga keuangan dan kelompok pemasaran yang belum banyak berperan sebagai lembaga pemasaran disentra-sentra produksi hal tersebut berdampak 
terhadap semakin rendahnya harga ditingkat petani karet. Mengatasi rendahnya harga karet di daerah, pemerintah daerah telah berupaya melalui program penyuluhan pada sub sektor perkebunan, untuk mendorong petani membentuk beberapa kelompok pemasaran di berbagai sentra produksi yang bertujuan untuk meningkatnya harga ditingkat petani.

Upaya meningkatkan keberhasilan dalam pengembangan kelompok pemasaran bersama bokar tidak terlepas dari kinerja penyuluh pertanian yang berkaitan dengan tingkat pengetahuan, keterampilan, motivasi, dan sikap penyuluh. Keberhasilan usaha kelompok pemasaran bokar akan dapat tercapai apabila terjadinya peningkatan pendapatan, dan adanya pengembangan usaha produktif oleh kelompok pemasaran tersebut sebagai wujud dari keberhasilan dalam mengembangkan usahanya.

Peningkatan kinerja penyuluh sangat berperan dalam pengembangan kelompok pemasaran secara bersama, namun ada beberapa faktor yang mempengaruhinya yaitu: pengetahuan, keterampilan, motivasi, jarak tempat tinggal, dan fasilitas. Penyuluh yang memiliki tempat tinggal yang jauh akan sulit untuk melakukan komunikasi dan kunjungan kepada petani atau kelompok sehingga akan mempengaruhi tingkat keberhasilan petani atau kelompoktani dalam mengembangan usahanya, berdasarkan hal tersebut maka dilakukan kajian tentang : "Kinerja Penyuluh Pertanian dan Keberhasilan Kelompok Pemasaran Bersama Bahan Olahan Karet Rakyat (Bokar) di Kabupaten Kuantan Singingi”.

\section{BAHAN DAN METODE}

\section{Tempat dan Waktu Penelitian}

Penelitian ini berlokasi di Kabupaten Kuantan Singingi, Propinsi Riau. Alasan pemilihan lokasi adalah: (1) lokasi ini merupakan sentra produksi karet; (2) adanya pabrik pengolahan karet/eksportir, yang merupakan lembaga pemasaran tertinggi sebagai objek penelitian; dan (3) daerah ini potensial untuk perkebunan karet dan akhir-akhir ini terus dikembangkan oleh pihak pemerintah daerah. Waktu penelitian ini direncanakan selama 12 (dua belas) bulan dimulai dari Bulan Januari 2017 sampai Desember 2017

\section{Penentuan Sampel}

Penelitian ini menggunakan metode survey terhadap sampel rumah tangga petani yang berusahatani karet pada kelompok pemasaran bersama dan terhadap penyuluh pertanian subsektor perkebunan yang bertugas dalam mengembangkan kelompok pemasaran bersama bokar.

Desa dan Kecamatan sampel dipilih secara multistage dimana adanya kelompok pemasaran bersama bahan olahan karet rakyat pada wilayah kecamatan yang lebih aktif di Kabupaten Kuantan Singingi. Demi kebutuhan tersebut maka dipilih sebanyak tiga 
kecamatan yaitu Kecamatan Kuantan Tengah, Kecamatan Benai, dan Kecamatan Sentajo Raya.

Responden petani dalam penelitian ini ditentukan secara proposional yaitu $10 \%$ dari setiap kelompok pada kecamatan yang diteliti.Jumlah sampel ditentukan berdasarkan rumus Slovin (Consuelo, 1993).

Rumus Slovin : $\mathrm{n}=\frac{N}{1+N \alpha^{2}}$

Lokasi, nama kelompok dan sampel penelitian dapat dijelaskan pada Tabel 1.

Tabel 1. Lokasi, Nama Kelompok, Sampel Penyuluh dan Petani dalam Pengembangan Kelompok Pemasaran Bersama

\begin{tabular}{|l|l|l|r|r|r|}
\hline No & \multicolumn{1}{|c|}{$\begin{array}{c}\text { Kecamatan/ } \\
\text { Desa }\end{array}$} & Nama Kelompok & $\begin{array}{c}\text { Anggota } \\
\text { (orang) }\end{array}$ & $\begin{array}{c}\text { Sampel } \\
\text { Petani } \\
\text { (orang) }\end{array}$ & $\begin{array}{c}\text { Sampel } \\
\text { Penyuluh } \\
\text { (orang) }\end{array}$ \\
\hline 1 & Gunung Toar/Gunung & Berkah Ilahi & 60 & 14 & 4 \\
\hline 2 & Benai/Banjar Benai & Gapoktan Sepakat & 100 & 22 & 3 \\
\hline 3 & Sentajo Raya/Jalur Patah & Saiyo Sekato & 184 & 41 & 4 \\
\hline Jumlah & $\mathbf{3 4 4}$ & $\mathbf{7 7}$ & $\mathbf{1 1}$ \\
\hline
\end{tabular}

\section{Jenis dan Sumber Data}

Data yang dikumpulkan dalam penelitian ini meliputi data primer dan data sekunder. Data primer diperoleh langsung dari petani sampel sedangkan data sekunder yaitu data yang diambil dari instansi terkait yang berkaitan dengan penelitian.

\section{Metode Analisis Data}

Sikap penyuluhan pertanian mengenai pengembangan kelompok pemasaran bersama bokar diukur dengan menerapkan "Skala likert" Sugiyono, (2007:134) menjelaskan bahwa skala likert's digunakan untuk mengukur sikap, pendapat, dan persepsi seseorang atau kelompok orang tentang fenomena sosial. Jawaban dari skala likert's mempunyai gradasi dari positif sampai negatif.

Variabel kinerja, pengetahuan, keterampilan, motivasi, jarak tempat tinggal, fasilitas penyuluhan pertanian dan keberhasilan petani (anggota kelompok) dalam pemasaran bersama bokar diukur dengan skala jenjang lima $(1,2,3,4,5)$. Untuk pertanyaan positif respon sangat setuju diberi skor 5 , sebaliknya sangat tidak setuju diberi skor 1 . Perolehan total skor disajikan dalam bentuk persen (\%) berdasarkan jumlah skor maksimum ideal maksimum ideal dengan rumus sebagai berikut :

$$
\text { Proporsi skor }=\frac{X}{S M I} \times 100 \%
$$

Dimana :

$\mathrm{X}=$ Perolehan skor

$\mathrm{SMI}=$ Skor maksimum ideal 
Untuk menentukan Interval kelas yang dikemukakan oleh Dajan (1986), dengan rumus :

$\mathrm{I}=\frac{\text { Kisaran proporsi }}{\text { Banyaknya } \text { kategori }}$

Dimana :

$\mathrm{I}=$ Interval kelas

Kisaran proporsi $=$ persentase pencapaian $\%$ skor maksimal- $\%$ pencapaian minimal

Banyaknya kategori = Jumlah kategori yang ditentukan

Dengan menggunakan rumus interval kelas tersebut maka dapat diketahui nilai kategori untuk setiap variabel seperti pada Tabel 2.

Tabel 2. Kategori Penilaian Kinerja Penyuluh Pertanian dan Tingkat Keberhasilan Petanidalam Pengembangan Pemasaran Secara Bersama di Kabupaten Kuantan Singingi

\begin{tabular}{|c|c|c|c|c|c|}
\hline \multirow[b]{2}{*}{ Indikator } & \multicolumn{5}{|c|}{ Skala Penilaian } \\
\hline & $>84-100$ & $>64-84$ & $>52-68$ & $>36-52$ & $20-36$ \\
\hline $\begin{array}{l}\text { Kinerja Penyuluh } \\
\text { Pengetahuan } \\
\text { Keterampilan } \\
\text { Motivasi } \\
\text { Sikap } \\
\text { Jarak tempat tinggal } \\
\text { Fasilitas } \\
\text { Keberhasilan petani }\end{array}$ & $\begin{array}{l}\text { Sangat baik } \\
\text { Sangat tinggi } \\
\text { Sangat terampil } \\
\text { Sangat kuat } \\
\text { Sangat baik } \\
\text { Sangat dekat } \\
\text { Sangat lengkap } \\
\text { Sangat berhasil }\end{array}$ & $\begin{array}{l}\text { Baik } \\
\text { Tinggi } \\
\text { Terampil } \\
\text { Kuat } \\
\text { Baik } \\
\text { Dekat } \\
\text { Lengkap } \\
\text { Berhasil }\end{array}$ & $\begin{array}{l}\text { Sedang } \\
\text { Sedang } \\
\text { Cukup } \\
\text { terampil } \\
\text { Sedang } \\
\text { Cukup Baik } \\
\text { Sedang } \\
\text { Sedang }\end{array}$ & $\begin{array}{l}\text { Rendah } \\
\text { Rendah } \\
\text { Kurang terampil } \\
\text { Rendah } \\
\text { Kurang Baik } \\
\text { Jauh } \\
\text { Kurang lengkap } \\
\text { Rendah }\end{array}$ & $\begin{array}{l}\text { Sangat rendah } \\
\text { Sangat rendah } \\
\text { Tidak terampil } \\
\text { Sangat rendah } \\
\text { Tidak Baik } \\
\text { Sangat jauh } \\
\text { Tidak lengkap } \\
\text { Sangat rendah }\end{array}$ \\
\hline
\end{tabular}

\section{HASIL DAN PEMBAHASAN}

Berdasarkan hasil penelitian kinerja penyuluh pertanian dilihat dari sifat personality dan hasil dalam mengembangkan usaha kelompok pemasaran bokar secara bersama di Kabupaten Kuantan Singingi dikategorikan "baik" dengan skala penilaian 79,58, hal ini disebabkan oleh penyuluh memiliki sikap tekun, disiplin, kerja keras, bertanggung jawab, inovativ, kreatif dan memiliki sikap teladan.

\section{Kinerja Berdasarkan Sifat Personalitas}

Penyuluh pertanian yang dijadikan responden berjumlah 11 orang. Untuk kinerja penyuluh pertanian yang berdasarkan rata-rata sifat personality kategori baik dengan skala penilaian $79,18 \%$ seperti pada Tabel 3 .

Tabel 3 Kinerja Penyuluh Pertanian Berdsarkan Sifat Personalitas

\begin{tabular}{c|l|l|l}
\hline No & \multicolumn{1}{|c|}{ Sifat Personalitas } & \multicolumn{1}{c}{ Rataan Skor } & \multicolumn{1}{c}{ Kategori } \\
\hline 1 & Tekun & 76,97 & Baik \\
2 & Disiplin & 87,27 & Sangat Baik \\
3 & Kerja Keras & 81,82 & Baik \\
4 & Bertanggung Jawab & 78,18 & Baik \\
5 & Inovatif & 80,91 & Baik \\
6 & Kreatif & 74,55 & Baik \\
7 & Teladan & 74,55 & Baik \\
\hline & Total & 554,24 & \\
\hline & Rataan & 79,18 & Baik \\
\hline
\end{tabular}


Penyuluh pertanian dalam mengembangkan kelompok pemasaran bersama bokar memiliki semangat yang tinggi, tekun, disiplin, kerja keras, memiliki rasa tanggung jawab yang besar, inovatif dan kreatif dalam mengembangkan kelompok pemasaran bokar. Sikap ketekunan yang dimiliki oleh penyuluh pertanian terlihat dari sikap rajin dalam melakukan kegiatan pengembangan kelompok pemasaran, konsisten dalam mengambil sikap, serta selalu melakukan kegiatan yang kontinyu sehingga kelompok pemasaran bersama dalam memasarkan bokar selalu mengalami peningkatan baik jumlah anggota maupun jumlah volume bokar yang dipasarkan, meningkatnya jumlah volume bokar disebabkan karena bertambahnya jumlah anggota kelompok, hal ini disebabkan karena petani memiliki kesadaran untuk mau bergabung dengan tujuan meningkatkan pendapatan, perbedaan harga bokar yang dijual melalui sistem lelang dengan menjual secara sendiri-sendiri berkisar Rp.3000, s/d Rp 3500 per kilogram.

Sikap disiplin penyuluh petanian memiliki kategori sangat baik hal ini terlihat dari ketertiban dalam melakukan pekerjaan seperti membuat RDK dan RDKK, RAT (rapat akhir tahun) dan membuat laporan hasil kegiatan di lapangan, patuh terhadap atasan dan aturan yang berlaku. Sikap disiplin juga terlihat dari ketepatan waktu penyuluh dalam melakukan kegiatan, seperti melakukan pertemuan dengan anggota kelompok, tepat waktu dalam melakukan penyuluhan, tepat waktu dalam penyampaian laporan dan sebagainya.

Sifat personalitas dilihat dari indikator kerja keras dan lama waktu bekerja memiliki kategori baik hal ini terlihat dari kesungguhan penyuluh dalam mengembangkan kelompok pemasaran bersama, penyuluh tidak mengenal lelah dan mengenal waktu dalam mendampingi kegiatan kelompok dalam melakukan kegiatan lelang bokar bahkan setiap kegiatan pelelangan selalu didampingi oleh penyuluh.

Sifat personalitas dilihat dari indikator inovatif bentuk inovatif yang dilakukan oleh penyuluh adalah selalu menerapkan hal-hal yang baru dan mencari hal-hal yang baru yang dibutuhkan oleh petani dalam meningkatkan pendapatan petani, seperti mengadakan penjualan bokar dengan sistem lelang, meningkatkan mutu dan kadar karet kering, membuka usaha warung saprodi dengan memanfaatkan modal kelompok, membuat kantor sekretariat kelompok, menganjurkan bahan pembeku lateks yang ekonomis, dan ramah lingkungan seperti penggunaan Deurob dan asam semut. Berdasarkan hasil penelitian Sasmi, 2016 tentang Pengentasan Kemiskinan Petani Karet Melalui Peningkatan Mutu Bokar dan Pengembangan Kelompok Pemasaran Bersama dengan Sistem Lelang di Desa Banjar Benai Kabupaten Kuantan Singingi. Hasil penelitian menunjukkan bahwa penggunaan bahan pembeku deurob menunjukkan hasil yang lebih 
baik dibanding bahan lainnya dilihat dari kadar kering lebih tinggi yaitu sebesar 88,56\%, tingkat elastisitas lebih tinggi yaitu 75,9, tidak berbau, dan ramah lingkungan. Permasalahan pada pemasaran karet dengan harga bervariasi karena disebabkan dalam penjualan belum dilakukan uji kadar kering harga ditaksir berdasarkan perkiraan dan masih dilihat secara visual. Penetapan kadar karet kering ditingkat kelompok berkisar antara 56\% s/d 60\%, sedangkan ditingkat pedagang pengumpul hanya berkisar $48 \% \mathrm{~s} / \mathrm{d}$ $50 \%$. Rendahnya penetapan kadar karet kering disebabkan oleh mutu bokar yang rendah sehingga akan berpengaruh terhadap harga yang lebih rendah.

Kinerja penyuluh berdasarkan indikator kreatif memiliki kategori baik hal ini penyuluh selalu menghasilkan ide baru dalam mengembangkan kelompok pemasaran seperti dengan mempertahan mutu bokar dengan membuat suatu aturan dan sangsi pada anggota jika anggota tidak melaksanakan bokar bersih dan dalam penyimpan tidak dilakukan perendaman, mendampingi setiap ada kegiatan pemasaran dan musyawarah dalam pengambilan keputusan. Proses penjualan dengan sistem pelelangan dilakukan secara tertutup melalui telephon seluler atau dengan mengumpul kertas yang ditulis harga oleh masing-masing pedagang pada saat pelelangan, harga tertinggi merupakan pemenang lelang. Pedagang yang ikut dalam proses lelang bersal dari dalam daerah dan luar daerah seperti Jambi, pekanbaru, Sumatera Barat, Palembang dan Medan. Untuk mempermudah informasi pelelangan rencana kedepan informasi pemasaran sistem lelang dapat di peroleh melalui webside kelompok pemasaran bersama bokar.

Kinerja penyuluhan berdasarkan sifat personalitas dilihat dari indikator teladan, dapat disimpulkan bahwa sifat ketauladan memiliki kategori baik, hal ini terlihat penyuluh mampu memberi contoh yang baik bagi petani. Ketauladanan penyuluh terlihat dari sikap dan prilaku adalah selalu jujur, hidup sederhana, disiplin, memiliki kasih sayang, tanggung jawab, selalu rajin, adil dan bijaksana. Selain itu terlihat dari hasil wawancara dengan beberapa petani penyuluh mampu menjadi contoh yang baik dalam bersikap dan berperilaku bagi orang-orang di sekitarnya; menjadi sumber inspirasi, tempat bertanya dan meminta nasihat bagi petani.

\section{Kinerja Berdasarkan Hasil Kerja}

Penyuluh pertanian memiliki kinerja berdasarkan hasil dalam kategori rata-rata kinerja penyuluh berdasarkan hasil yaitu memiliki kategori baik dengan skala penilaian sebesar 79,94\%. Rincian data selengkapnya mengenai kinerja penyuluh pertanian berdasarkan hasil penelitian dapat dilihat dalam Tabel 4.

Tabel 4 Kinerja Penyuluh Pertanian Berdasarkan Hasil yang Dilaksanakan

\begin{tabular}{c|l|c|c}
\hline No & Hasil & Rataan Skor & Kategori \\
\hline \multicolumn{1}{|c|}{107} & $\begin{array}{l}\text { Kinerja Penyuluh Pertanian Dan Keberhasilan Kelompok Pemasaran Bersama Bahan } \\
\text { Olahan Karet Rakyat (Bokar) Di Kabupaten Kuantan Singingi }\end{array}$ \\
\hline
\end{tabular}




\begin{tabular}{l|l|l|l}
\hline 1 & Frekuensi Penyuluhan & 76,97 & Baik \\
2 & Materi Penyuluhan & 78,91 & Baik \\
3 & Program Penyuluhan & 82,73 & Baik \\
4 & Kehadiran Sasaran & 76,36 & Baik \\
5 & Interaksi Penyuluh dengan Kelompok Tani & 87,27 & Sangat Baik \\
6 & Perubahan Perilaku Sasaran & 89,09 & Sangat Baik \\
7 & Perkembangan Kegiatan Pemasaran Bersama & 75,45 & Baik \\
& Bokar & & \\
8 & Manajemen Usaha Pemasaran Bersama Bokar & 72,73 & Baik \\
\hline & Total & 639,52 & \\
\hline & Rataan & 79,94 & Baik \\
\hline
\end{tabular}

Indikator kinerja berdasarkan hasil terlihat pada Tabel 4 bahwa dari frekuensi penyuluhan memiliki kategori baik seperti pada frekuensi bertemu penyuluh dengan petani, frekuensi kehadiran dalam setiap kegiatan penyuluhan tinggi yaitu rata-rata dilakukan tiga kali seminggu, petani dan penyuluh saling berintegrasi dan selalu melakukan diskusi dan memecahkan masalah secara bersama. Dalam kegiatan penyuluhan usaha pengembangan pemasaran bokar penyuluh menyampaikan materi sesuai dengan kebutuhan petani terkait dengan peningkatan mutu bokar, pengolahan bokar yang baik, penyimpanan bokar, pengelolaan kelompok yang baik, penggunaan pembeku lateks yang ramah lingkungan serta bagaimana melakukan pemasaran yang lebih efisien.

Kinerja penyuluh berdasarkan hasil pada indikator program penyuluhan terlihat baik hal ini terlihat adanya program tersusun dengan baik, adanya tabel rencana kerja yang baik. Penyusunan program dilakukan sesuai dengan kebutuhan kelompok pemasaran bersama bokar dilakukan oleh penyuluh pertanian dengan beberapa tahapan yaitu 1) tahap perumusan masalah, 2) penetapan tujuan, 3) penetapan masalah, 4) penetapan rencana kegiatan, 5) rencana monitoring dan evaluasi. Menurut penelitian Putri,I.W et all, 2016 tentang Pelatihan non teknis terhadap kinerja penyuluhan pertanian BP4K di Kabupaten Bungo Provinsi Jambi menunjukkan bahwa kontinuitas monitoring dan evaluasi kegiatan penyuluh pertanian merupakan hasil pekerjaan penyuluh pertanian dalam pemantauan, penilaian dan pelaporan kegiatan penyuluh pertanian. Beberapa faktor yang menyebabkan kinerja cukup baik adalah adanya pertemuan rutin setiap awal bulan sekaligus pelatihan di BP3K unit kerja masing-masing yang dipimpin oleh kepala dinas BP3K atau yang mewakili.

Kehadiran sasaran memiliki kategori baik hal ini dilihat dari tingkat kehadiran petani dalam pertemuan kelompok kategori baik, penyuluh juga mengetahui alasan ketidak hadiran anggota dalam melakukan pertemuan, hal ini diketahui dari absensi kehadiran petani. Indikator interaksi penyuluh dengan kelompoktani memiliki kategori sangat baik hal ini terlihat adanya komunikasi yang baik dengan kelompok sehingga 
tercipta keakraban, serta penyuluh juga melakukan kunjungan ke kelompoktani untuk melihat perkembangan kelompok dalam memasarkan bokar secara rutin dilakukan 3-4 kali seminggu.

Komunikasi yang baik akan terjalin kerjasama yang baik, pesan yang disampaikan oleh penyuluh akan diterima baik oleh petani dan akan terjadi perubahan perilaku sasaran dalam perkembangan kegiatan pemasaran bokar. Perubahan perilaku ini antara lain adanya kesadaran petani karet dalam merubah pola pikir bahwa perlu peningkatan mutu bokar yaitu dengan tidak merendam, tidak memasukkan kotoran, serta menggunakan bahan pembeku lateks sesuai teknis, serta dengan memasarkan bokar secara efisien yaitu dengan sistem lelang. Dengan adanya sistem lelang ini maka terjadi peningkatan pendapatan petani dan diharapkan dengan meningkatnya kesadaran petani maka akan berkembang kelompok-kelompok pemasaran baru disetiap sentra produksi.

\section{Pengetahuan Penyuluh Pertanian dalam Pengembangan Kelompok Pemasaran Bersama Bokar}

Pengetahuan penyuluh sangat erat kaitannya dengan peningkatan kemampuan kerja penyuluh. Pengetahuan juga tidak terlepas dari tingkat pendidikan dan bagaimana sesorang memiliki kemampuan untuk mau belajar dan mampu mengembangkan ilmu dan teknologinya yang lebih inovatif. Sejalan menurut Soekartawi, 2005 semakin tinggi pendidikan sesorang semakin tinggi pula pengetahuan, sikap, keterampilan dan efisiensi bekerja serta semakin mengetahui teknik bekerja yang lebih menguntungkan. Berdasarkan tingkat pengetahuan penyuluh pertanian tentang pemahamannya terhadap pengertian penyuluh, prinsip-prinsip penyuluhan, metode penyuluhan, merencanakan penyuluhan dan melaksanakan penyuluhan memiliki kategori baik. Penyuluh memahami bahwa hakekat penyuluh adalah kemampuan meningkatkan pengetahuan dan keterampilan, mengetahui berbagai metode penyuluhan yaitu pendekatan perorangan, kelompok dan masal. Perencanaan penyuluhan dengan membuat rencana kerja tersusun dengan baik dan dibuat tertulis sudah disahkan pimpinan, dan rencana kerja telah disusun secara sitematis berdasarkan kebutuhan oleh petani. Hasil penelitian terlihat pengetahuan penyuluh pertanian secara rinci dapat dilihat pada Tabel 5 .

Tabel 5. Distribusi Penyuluh Pertanian Berdasarkan Pengetahuan dalam Pengembangan UsahaPemasaran Bersama Bokar

\begin{tabular}{c|l|l|l}
\hline No & Pengetahuan Penyuluh & \multicolumn{1}{|c}{ Rataan Skor } & \multicolumn{1}{c}{ Kategori } \\
\hline 1 & Pengertian Penyuluhan & 84,24 & Baik \\
2 & Metode Penyuluhan & 89,70 & Sangat Baik \\
3 & Perencanaan Penyuluhan & 83,64 & Baik \\
4 & Pelaksanaan Penyuluhan & 62,27 & Cukup Baik \\
\hline & Total & 319,85 & \\
\hline & Rataan & 79,96 & Baik \\
\hline
\end{tabular}




\section{Keterampilan Penyuluh dalam Mengembangkan Kelompok Pemasaran Secara Bersama}

Keterampilan penyuluh pertanian pada penelitian ini memiliki kategori baik dilihat dari kemampuan menyuluh, kreatifitas, dan penggunaan alat bantu. Dari hasil penelitian ini penyuluh pertanian telah mampu dan kreatif dalam menyusun perencanaan penyuluhan seperti : Menyusun program penyuluhan bagi wilayah kerjanya; Menetapkan impact point dan mencari pemecahannya; Melakukan kunjungan lapangan, melaksanakan demonstrasi dan pembinaan kegiatan kelompok tani dalam mengembangkan kelompok agar menjadi kekuatan ekonomi dan sosial bagi masyarakat sekitarnya.

Kemampuan penyuluh dilihat dari konsep penyuluhan sering melaksanakan berorientasi agribisnis dan terlihat perubahan perilaku petani kearah yang lebih maju seperti telah memiliki kesadaran dalam melaksankan bokar bersih dan bergabung dengan kelompok pemasaran secara bersama. Mampu menyampaikan materi sesuai kebutuhan. Kemampuan dalam menerapkan teknologi cukup terjadi perobahan kepada petani yaitu dengan memanfaatkan aplikasi dan jaringan internet dalam mencari informasi harga dasar dan menginformasikan harga ditingkat kelompok yang memasarkan secara bersama, adanya transparansi harga. Dalam menggunakan pembeku lateks petani juga sudah memahami terhadap penggunaan pembeku yang ramah lingkungan. Pada saat melakukan penyuluhan penyuluh telah memiliki kemampuan menggunakan alat bantu jika diperlukan seperti LCD protektor. Berdasarkan tingkat keterampilan penyuluh dalam pengembangan usaha pemasaran bersama bokar secara rinci dilihat pada Tabel 6.

Tabel 6 Distribusi Penyuluh Pertanian Berdasarkan Keterampilan dalam Pengembangan Usaha Pemasaran Bersama Bokar

\begin{tabular}{c|l|l|l}
\hline No & \multicolumn{1}{|c|}{ Keterampilan Penyuluh } & \multicolumn{1}{|c}{$\begin{array}{c}\text { Rataan } \\
\text { Skor }\end{array}$} & \multicolumn{1}{c}{ Kategori } \\
\hline 1 & Kemampuan Menyuluh & 74,55 & Baik \\
2 & Kreativitas & 76,36 & Baik \\
3 & Penggunaan Alat Bantu & 70,91 & Baik \\
\hline & Total & 221,82 & \\
\hline & Rataan & 73,94 & Baik \\
\hline
\end{tabular}

\section{Kinerja Berdasarkan Motivasi}

Pelaksanaan tugas penyuluh pertanian dipengaruhi oleh beberapa faktor salah satunya adalah motivasi yang terbentuk dari sikap seseorang dalam menghadapi situasi kerja. Hasil penelitian menunjukkan bahwa motivasi memiliki kategori baik dilihat dari tingkat gaji, prestasi, hubungan interpersonal dan harapan untuk maju seperti terlihat pada Tabel 7.

Tabel 7. Distribusi Penyuluh Pertanian Berdasarkan Motivasi dalam Pengembangan Usaha Pemasaran Bersama Bokar

\begin{tabular}{c|l|c|c}
\hline No & \multicolumn{1}{c}{ Motivasi Penyuluh } & Rataan Skor & Kategori \\
\hline \hline 110 & $\begin{array}{l}\text { Kinerja Penyuluh Pertanian Dan Keberhasilan Kelompok Pemasaran Bersama Bahan } \\
\text { Olahan Karet Rakyat (Bokar) Di Kabupaten Kuantan Singingi }\end{array}$ \\
\hline
\end{tabular}




\begin{tabular}{l|l|l|l}
\hline 1 & Tingkat Gaji & 69,09 & Baik \\
2 & Prestasi & 75,45 & Baik \\
3 & Hubungan Interpersonal & 82,42 & Baik \\
4 & Harapan Untuk Maju & 64,55 & Baik \\
\hline & Total & 291,52 & \\
\hline & Rataan & 72,88 & Baik \\
\hline
\end{tabular}

Penyuluh pertanian pada penelitian ini memiliki tingkat gaji yang baik karna sebesar 73\% merupakan Pegawai Negeri Sipil yang memiliki gaji > 3 juta, sebesar 27\% merupakan tenaga honorer memiliki gaji >1,5 juta-3 juta, prestasi yang diperoleh sebagian dari penyuluh telah memiliki prestasi penyuluh terbaik dan berprestasi dalam membina kelompok pemasaran bersama bokar sehingga telah membantu peningkatan pendapatan petani karet, Hubungan interpersonal juga baik hal ini terlihat dari adanya kerjasama yang baik dan keakraban dalam jalinan relasi sosial dengan pimpinan, sesama penyuluh dan petani, suasana kerja yang baik akan mendorong meningkatnya motivasi.

Sejalan dengan hasil penelitian yang dilakukan oleh Siregar dan Saridewi, 2010 tentang hubungan antara motivasi dan budaya kerja dengan kinerja penyuluhan pertanian di Kabupaten Subang Provinsi Jawa Barat. Hasil penelitian menunjukkan bahwa terdapat hubungan yang kuat antara motivasi dengan kinerja penyuluh pertanian, secara parsial motivasi memberikan kontribusi sebesar $56 \%$ terhadap kinerja, secara bersama-sama memberikan pengaruh sebesar $66 \%$.

\subsection{Sikap Penyuluh Pertanian dalam Mengembangkan Kelompok Pemasaran Bokar}

Sikap merupakan hal yang penting diperhatikan bagi seorang penyuluh karna sikap merupakan cerminan pribadi yang akan menjadi panutan orang lain. Sebagai seorang penyuluh harus memberikan contoh yang baik bagi petani dan masyarakat. Penyuluh harus memiliki sikap bekerja dengan tulus, keteguhan hati dan keyakinan untuk maju dari sikap penyuluh terlihat pada Tabel 8 dengan kategori sangat baik. Dari ketiga sikap tersebut tergambar pada penyuluh bahwa bekerja tanpa imbalan dari petani, selalu yakin bahwa dalam mengembangkan kelompok pemasaran secara bersama bertujuan untuk memberikan hasil yang mampu meningkatkan pendapatan petani.

Tabel 8 Distribusi Penyuluh Pertanian Berdasarkan Sikap dalam Pengembangan Usaha Pemasaran Bersama Bokar

\begin{tabular}{c|l|l|l}
\hline No & \multicolumn{1}{|c|}{ Sikap Penyuluh } & \multicolumn{1}{c}{ Rataan Skor } & \multicolumn{1}{c}{ Kategori } \\
\hline 1 & Ketulusan & 87,27 & Sangat Baik \\
2 & Keteguhan Hati & 87,27 & Sangat Baik \\
3 & Keyakinan & 87,27 & Sangat Baik \\
\hline & Total & 261,81 & \\
\hline & Rataan & 87,27 & Sangat Baik \\
\hline
\end{tabular}




\section{Jarak Tempat Tinggal Penyuluh Pertanian dalam Pengembangan Kelompok Pemasaran Secara Bersama Bokar}

Tempat tinggal penyuluh pertanian rata-rata tergolong dekat, jarak yang dekat akan mempermudah dalam kegiatan penyuluhan yang dilakukan. Semakin dekat jarak maka akan semakin mudah dalam berinteraksi dengan petani atau anggota kelompok, sehingga akan mempermudah dalam melakukan pembinaaan kelompok.

Tabel 9 Distribusi Penyuluh Pertanian Berdasarkan Jarak dalam Pengembangan Usaha Pemasaran Bersama Bokar

\begin{tabular}{c|l|l|l}
\hline No & \multicolumn{1}{|c|}{ Jarak Tempat Tinggal } & Rataan Skor & \multicolumn{1}{c}{ Kategori } \\
\hline 1 & Keterjangkauan & 80,00 & Dekat \\
\hline & Total & 80,00 & \\
\hline & Rataan & 80,00 & Dekat \\
\hline
\end{tabular}

Fasilitas Penyuluh Pertanian Dalam Pengembangan Kelompok Pemasaran Bersama Bokar

Sarana dan prasarana sebagai penunjang kegiatan penyuluhan masih kurang lengkap baru tersedia sekitar 60\%-80\%, kurang lengkapnya sarana dan prasara tidak mengurangi semangat dan kinerja penyuluh dalam melakukan aktivitas kerjanya. Pada saat ini kondisi bangunan masih belum milik sendiri yaitu masih memanfaatkan gedung Ex SRDP di setiap UPTD, kebutuhan ruangan belum sesuai standar seperti adanya ruang pimpinan, TU, Aula, perpustakaan dan data system informasi, gudang, pagar, dan lahan percontohan. Sedang sarana umumnya komputer milik pribadi, alat bantu hanya memiliki whiteboard. Transportasi roda dua juga sebagian milik sendiri, Mebeulair seperti kursi meja masih kurang seperti tidak memiliki peralatan dapur, rak buku pustaka, peralatan makan dan minum, peralatan dapur serta belum memiliki buku dan hasil publikasi. Hasil penelitian Firmansyah (2013) tentang motivasi, Kepuasan kerja dan kinerja penyuluhan kehutanan di Kabupaten Cianjur Jawa Barat menyatakan bahwa salah satu dukungan lembaga penyuluhan yang dapat diberikan kepada penyuluh agar memudahkannya untuk bekerja. Secara rinci fasilitas dalam pengembangan usaha pemasaran bersama bokar dapat dilihat pada Tabel 10 .

Tabel 10 Distribusi Penyuluh Pertanian Berdasarkan Fasilitas dalam Pengembangan Usaha Pemasaran Bersama Bokar

\begin{tabular}{c|l|c|c}
\hline No & \multicolumn{1}{|c|}{ FasilitasPenyuluh } & Rataan Skor & Kategori \\
\hline 1 & Sarana dan Prasarana & 45,45 & Kurang Lengkap \\
\hline & Total & 45,45 & \\
\hline & Rataan & 45,45 & Kurang Lengkap \\
\hline
\end{tabular}

Keberhasilan Anggota Kelompok Pemasaran Bersama dalam Memasarkan Bokar 
Keberhasilan anggota kelompok dalam mengembangkan usaha kelompok pemasaran bokar secara bersama di Kabupaten Kuantan Singingi di kategorikan "berhasil" dengan skala penilaian 77,58. Keberhasilan ini dilihat dari bertambahnya jumlah anggota dan volume bokar, meningkatnya mutu dan kadar karet kering bokar, adanya perubahan teknologi dengan penggunaan bahan pembeku lateks yang aman terhadap lingkungan dan bermutu, meningkatnya pendapatan anggota, bertambahnya modal kelompok, adanya informasi pasar yang transparan. Tingkat keberhasilan kelompok pemasaran bokar secara bersama dapat dijelaskan secara rinci pada Tabel 11 .

Tabel 11 Keberhasilan Anggota Kelompok Pemasaran Bersama dalam Memasarkan Bokar

\begin{tabular}{l|l|l|l}
\hline No & $\begin{array}{c}\text { Keberhasilan Anggota Kelompok } \\
\text { Pemasaran }\end{array}$ & Rataan Skor & Kategori \\
\hline 1 & Pertambahan Volume Penjualan & 40,52 & Rendah \\
2 & Persentase Kadar Kering Karet & 100,00 & Sangat Baik \\
3 & Pengolahan Bokar & 83,72 & Baik \\
4 & Pendapatan Anggota & 67,01 & Cukup Baik \\
5 & Jumlah Usaha yang Dimiliki & 45,45 & Rendah \\
6 & Penerapan Teknologi & 88,57 & Sangat Baik \\
7 & Permodalan & 100,00 & Sangat Baik \\
8 & Pemasaran & 83,12 & Baik \\
\hline & Total & 608,40 & \\
\hline & Rataan & 76,05 & Baik \\
\hline
\end{tabular}

Keberhasilan petani merupakan suatu hal yang sangat menentukan berhasil tidaknya kegiatan penyuluhan yang dilakukan, ha ini terlihat dari adanya perubahan perilaku sasaran terhadap meningkatnya produksi dan kemampuan merubah sikap petani yang lebih baik. Hasil penelitian terlihat bahwa peningkatan volume penjualan masih berkisar $>20-40 \%$ dengan kategori kurang meningkat, hal ini disebabkan karena produksi karet meningkat bukan karena adanya penambahan luas areal atau produksi tetapi bertambah akibat meningkatnya jumlah anggota yang menjual ke kelompok. Produksi karet sangat berbeda dengan produksi tanaman perkebunan lain karna sangat dipengaruhi oleh faktor iklim seperti pada saat musim penghujan dan kemarau petani tidak melakukan penyadapan, hal seperti ini yang menyebabkan rendahnya peningkatan volume penjual setiap pelelangan. Jumlah volume bokar setiap pelelangan berkisar antara 10-20 ton perminggu. Kadar karet kering ditingkat kelompok jauh lebih tinggi dibanding dengan penetapan kadar karet kering oleh pedagang pengumpul yaitu $>55 \%$, sedangkan ditingkat pedagang pengumpul $<50$.

Kelompok pemasaran secara bersama merupakan suatu lembaga pemasaran yang bertujuan meningkatkan pendapatan anggota maka perlu manajemen yang baik, setiap kelompok memiliki struktur organisasi kepengurusan yang baik, memiliki rencana kerja, pembukuan keuangan yang baik, adanya simpanan pokok, simpan pinjam, uang kas dan 
modal yang telah terkumpul hingga ada yang mencapai Rp. 200.000.000,-. Pada saat ini penyuluh pertanian berupaya membina kearah pengembangan kelompok dengan merencanakan pengembangan usaha seperti terbentuknya KUD. Sebagian kelompok telah mengembangkan usaha produktif seperti usaha pembitan kakao, warung saprodi. Pada saat ini dari uang kas yang ada akan digunakan untuk usaha penumpukkan modal dengan mengembangkan usaha kelompok pengadaan saprodi seperti pupuk, pestisida, alat pertanian, bahan pembeku lateks dan sebagainya, sehingga dari hasil penjualan tersebut dapat lagi digunakan dalam pengembangan usaha lainnya.

Modal kelompok diperoleh dari simpanan pokok anggota berjumlah Rp.100.000,-, simpanan wajib yaitu berupa tabungan anggota yang disisihkan berupa uang receh dari penjualan yang nilai kurang dari Rp.10.000,-, sebesar 5\% dari pinjaman anggota, 1\% dari keuntungan penjualan juga menjadi sumber pendapatan kelompok. Dari modal yang disimpan kelompok juga merencanakan membuka kedai sembako dan depot air minum. Meningkatnya usaha kelompok juga akan mampu meningkatkan pendapatan anggota karena keuntungan usaha kelompok merupakan keuntungan bagi semua anggota.

\section{KESIMPULAN DAN SARAN}

\section{Kesimpulan}

Berdasarkan hasil penelitian maka dapat disimpulkan sebagai berikut :

1. Kinerja penyuluh berdasarkan pertanian dalam pengembangan kelompok pemasaran secara bersama bokar di Kabupaten Kuantan Singingi termasuk kategori baik.

2. Faktor-faktor yang berhubungan dengan kinerja, pengetahuan, keterampilan, Motivasi baik, sikap sangat baik, jarak tempat tinggal dekat, fasilas kurang lengkap, dan tingkat keberhasilan kategori berhasil.

3. Keberhasilan anggota kelompok dalam mengembangkan usaha kelompok pemasaran secara bersama di Kabupaten Kuantan Singingi termasuk kategori baik.

\section{Saran}

1. Mengingat pentingnya peran penyuluh dalam pengembangan kelompok pemasaran bersama bahan olahan karet rakyat perlunya perhatian pemerintah dalam peningkatan fasilitas penyuluh pertanian di Daerah agar kinerja penyuluh dapat lebih baik.

2. Perlu dilakukan penelitian lanjutan tentang peran pemerintah dan penyuluh dalam meningkatkan kinerja kelompok pemasaran bersama bahan olahan karet rakyat (bokar)

\section{DAFTAR PUSTAKA}

Consuole, G, Seveela. 1993. Pengantar Metode Penelitian. Jakarta: Universitas Indonesia Press. 
Dajan,A, 1986. Pengantar Metode Statistik Jilid II. Jakarta.LP3ES

Firmansyah, 2013. Motivasi, Kepuasan Kerja, dan Kinerja Penyuluhan Kehutanan di Kabupaten Cianjur Jawa Barat. Jurnal: Penyuluhan 11 (1): 11-22.

Sasmi, M, 2016. Pengentasan Kemiskinan Petani Karet Melalui Peningkatan Mutu Bokar dan Pengembangan Kelompok Pemasaran Bersama dengan Sistem Lelang di Desa Banjar Benai Kabupaten Kuantan Singingi. Jurnal: Uniks volume 3 Nomor 1 Januari-Maret/2016.

Siregar.AN, Saridewi.TR, 2010., Hubungan Antara Motivasi dan Budaya Kerja dengan Kinerja Penyuluh Pertanian di Kabupaten Subang, Provinsi Jawa Barat. Jurnal: Penyuluhan Pertanian Volume 5 Nomor 1 Tahun 2010.

Soekartawi, 2005. Prinsip Dasar Komunikasi Pertanian. Jakarta (ID): Universitas Indonesia.

Sugiyono, 2007. Statistika untuk Penelitian" Bandung: CV Alfabeta

Putri.I.W,Fatchiya.A, Amanah.S, 2016. Jurnal: Penyuluhan Volume 12 Nomor 1 Tahun 2016. 